\title{
Evaluation of Factors Affecting Elective Course Preferences: Example of Faculty of Veterinary Medicine Validity and Reliability Study
}

\author{
Gökhan ASLIM1**, Mustafa Agah TEKINDAL², Aşkın YAŞAR ${ }^{1}$ \\ ${ }^{1}$ Selcuk. University, Faculty of Veterinary Medicine, Department of History of Veterinary Medicine and Deontology, Konya, Turkey \\ ${ }^{2} \dot{I}_{z}$ mir Katip Celebi University, Faculty of Medicine, Department of Biostatictics, İzmir, Turkey
}

\begin{abstract}
This study aims to determine the factors affecting the elective course preferences of veterinary faculty students. Developing a scale (Elective Course Preference Attitude Scale) that provides an evaluation of the elective course preferences of students of veterinary medicine students is also aimed. 354 students studying at Selçuk University, Faculty of Veterinary Medicine in the 2019-2020 academic year participated in the study. With regard to constructing validity, Cronbach's alpha $(\alpha)$ coefficient was used for the reliability analysis. For validity analysis, factor analysis was applied. In light of the data obtained from the study, it can be suggested that the "Elective Course Preference Attitude Scale" is a valid and reliable tool in the evaluation of the elective course preferences of veterinary medicine students, and this scale can also be used in the evaluation of the elective course preferences of students of other departments.
\end{abstract}

Keywords: Elective course, Scale, Student, Veterinary faculty

Seçmeli Ders Tercihlerine Etki Eden Faktörlerin Değerlendirilmesi: Veteriner Fakültesi Örneği Geçerlik ve Güvenirlik Çalışması

ÖZ

$\mathrm{Bu}$ çalışma ile veteriner fakültesi öğrencilerinin seçmeli ders tercihlerine etki eden faktörlerin belirlenmesi amaçland1. Ayrıca veteriner fakültesi öğrencilerinin seçmeli ders tercihlerinin değerlendirilmesini sağlayan bir ölçeğin (Seçmeli Ders Tercihi Tutum Ölçeği) geliştirilmesi hedeflendi. Çalışmaya, Selçuk Üniversitesi Veteriner Fakültesi’nde 2019-2020 Eŭitim-Öğretim döneminde öğrenim görmekte olan 354 öğrenci katıldı. Yap1 geçerliliği için; güvenirlik analizlerinde Cronbach alfa $(\alpha)$ katsayısı kullanıldı. Geçerlik analizi için faktör analizi uygulandı. Çalışmada elde edilen veriler neticesinde “Seçmeli Ders Tercihi Tutum Ölçeği” nin veteriner fakültelerinde öğrenim görmekte olan öğrenciler için güvenilir ve geçerli olduğu; veteriner fakültesi öğrencileri seçmeli ders tercihlerinin değerlendirilmesinde kullanılabileceği gibi diğer bölümlerde öğrenim görmekte olan öğrencilerin seçmeli ders tercihlerinin değerlendirilmesinde kullanılabilecek bir ölçek olduğu da ileri sürülebilir.

Anahtar Kelimeler: Seçmeli ders, Ölçek, Öğrenci, Veteriner Fakültesi

To cite this article: Aslim G. Tekindal M.A. Yaşar A. Evaluation of Factors Affecting Elective Course Preferences: Example of Faculty of Veterinary Medicine Validity and Reliability Study. Kocatepe Vet J. (2020) 13(4):347-356

Submission: 29.06.2020 Accepted: 25.09.2020 Published Online: 10.11 .2020

ORCID ID; GA: 0000-0001-5976-8186, MAT: 0000-0002-4060-7048, AY: 0000-0001-8641-6207

*Corresponding author e-mail: gokhan.aslim@selcuk.edu.tr 


\section{INTRODUCTION}

In the world, the rapid change in science and technology affects people's lifestyles, the structure as well as the needs of the society, and the required human qualities and necessitates the training of individuals who are equipped in many aspects with different knowledge and skills (Durmuşçelebi and Mertoğlu 2018). In the process of training qualified manpower, one way to provide students with a better learning environment and opportunities is the elective courses, which the students can choose in accordance with their professional interests and personal skills during their university education (Dündar 2008, Durmuşçelebi and Mertoğlu 2018).

The criteria considered by the students in the selection of elective courses are generally subjective (Dündar 2008). Some subjects interest students more than the others because of several reasons. So, in return, universities offer many elective course alternatives to their students. The selection of the most suitable of the alternative courses for students is a complex decision process that requires the consideration of multiple factors and criteria (Ersöz et al. 2011). In this process, making the best choice in a situation where many criteria are at play is difficult as these criteria sometimes may be inconsistent (Kutlu et al. 2012). The findings obtained in different studies show that among the primary criteria for elective courses are contribution to professional life, course credit, and opinions on the lecturer (Tezcan and Gümüş 2008).

Allowing students to choose their own courses apart from the compulsory ones is also compatible with today's democratic understanding. Offering different alternatives to students will also enable them to develop positive attitudes towards the university. Elective courses contribute to students' cognitive (knowledge, skill) affective (interest, attitude), and social development. Students with different interests, needs, and abilities are offered different course options in the programs, and elective courses are also expected to accommodate students with the qualifications to acquire professional skills. In a world that is changing at an incredible pace, it is of great importance for students to develop their life skills in order to keep up with this rapid change (Ersöz et al. 2011).

In the light of this information, it was aimed to develop a scale that enables the evaluation and determination of the factors affecting the choice of elective courses of veterinary faculty students.

\section{MATERIAL and METHODS}

\section{Data collection form}

A data form whose power analysis was made before starting the study $(96.32 \%$ power) and in the preparation of which different sources (Tezcan and Gümüş 2008, Kutlu et al. 2010) were also utilized and consisting of 28 questions was applied in person to 354 bachelor students of Selçuk University, Faculty of Veterinary Medicine between the dates 4 and 12 April 2020.

\section{Statistical analyses}

In the study, reliability and validity analyzes were made for the "Elective Course Preference Attitude Scale". Cronbach alpha $(\alpha)$ coefficient was used for reliability analysis and factor analysis to determine validity. Suitability for factor analysis was evaluated using Bartlett's test of sphericity, and the sufficiency of the sample size was evaluated using the Kaiser-MeyerOlkin (KMO) sampling adequacy scale.

Descriptive statistics were given for categorical and continuous variables in the study. In the evaluation of the data, SPPS 25 Released 2017. IBM SPSS Statistics for Windows (Version 25.0. Armonk, NY: IBM

Corp.), statistical software package was used. $\mathrm{p}<0.05$ and p 0.01 level was considered statistically significant

\section{RESULTS}

Of the 354 Selcuk University Faculty of Veterinary Medicine students participating in the study, $60.2 \%$ are male and $39.8 \%$ are female. While the study was participated by senior year students the most $(27.7 \%)$, it was participated the least by the junior year students $(10.5 \%)$ (Table 1). There are no items with a total correlation value of less than 0.20 in the data form. Therefore, since all 28 items were determined to have a high level of reliability, no items were removed (Table 2).

For the reliability of the data form, since each item of the scale is measured by using a 5-point Likert scale, in terms of Cronbach's Alpha, the form is reliable with regard to internal consistency $(\alpha)$ Cronbach's alpha reliability coefficient value for the 28 -item data form used in the research $(\alpha)$ was calculated as 0.906 (Table 3).

In terms of the validity study of the data form, factor analysis was performed with the Varimax method for the data collected on the items in the form and the findings are presented in Table 4.

In the study, the Kaiser-Meyer-Olkin sampling adequacy was found to be 0.909 , the chi-square value of Bartlett's sphericity 4921,612, the degree of freedom 378, and $\mathrm{p}=0.001$.

When the total variance was analyzed, it was determined that according to the application data, there were 5 factors for 28 items, and they explain $59,089 \%$ of the measurement made by this scale. (Table 4).

Tukey's range test was applied to obtain a total scale score by the addition of the item scores. Considering the additivity line, $\mathrm{p}$ was determined as $>0.05$ (Table 5).

The enthalpy-entropy chart was used in the study (Figure 1). In the graph, the cut-off point of the 
eigenvalues represents the 5th main component. Therefore, the basic component may not be taken by determining 5 factors. However, since the study aimed to explain a larger part of the total variability, a 5 th main component was included.

In the study, no item was removed due to low factor load found in the load factor analysis. Questions 15 to 20 cover Factor 1 (Additive Factor), 21 to 25 cover
Factor 2 (Personal Factor), 1 to 10 cover Factor 3 (Structural Factor), 11 to 14 cover Factor 4 (Instructor Factor), and 26 to 28 cover Factor 5 (Environmental Factor). The sub-items collected in the factors were taken into consideration in the naming of each factor. The lowest item load was determined as 0,400 and the highest item load was determined as 0.829 (Table 6).

Table 1: Socio-Demographic data

\begin{tabular}{llll}
\hline & & $\mathbf{n}$ & $\mathbf{0}$ \\
\hline \multirow{3}{*}{ CR } & Term 1 & 90 & 25,4 \\
& Term 2 & 74 & 20,9 \\
& Term 3 & 37 & 10,5 \\
Gender & Term 4 & 98 & 27,7 \\
Total & Term 5 (Intern) & 55 & 15,5 \\
& Female & 141 & 39,8 \\
\hline
\end{tabular}

Table 2: Item-based reliability coefficients and item-total correlation of the scale

\begin{tabular}{|c|c|c|c|c|}
\hline & $\begin{array}{l}\text { Average to be } \\
\text { valid if an item } \\
\text { is removed } \\
\text { from the scale }\end{array}$ & $\begin{array}{l}\text { Variance to } \\
\text { be valid if an } \\
\text { item is } \\
\text { removed from } \\
\text { the scale }\end{array}$ & $\begin{array}{l}\text { Total } \\
\text { Item } \\
\text { Correlations }\end{array}$ & $\begin{array}{l}\text { Reliability to be } \\
\text { valid if an item is } \\
\text { removed from the } \\
\text { scale } \\
\text { Cronbach's } \alpha \\
\text { Coefficient }\end{array}$ \\
\hline $\begin{array}{l}\text { [1. The "content of the course" affects } \\
\text { my elective course choice.] }\end{array}$ & 99,9605 & 320,078 & 0,535 & 0,902 \\
\hline $\begin{array}{l}\text { [2. The "course selection system" } \\
\text { affects my elective course choice. }\end{array}$ & 100,2288 & 326,880 & 0,380 & 0,905 \\
\hline $\begin{array}{l}\text { [3. The "way the course is taught } \\
\text { (traditional, student research, } \\
\text { presentations, etc.)" affects my elective } \\
\text { course choice.] }\end{array}$ & 99,9915 & 317,300 & 0,571 & 0,901 \\
\hline $\begin{array}{l}\text { [4. The "class hours (whether the class } \\
\text { is in the morning or afternoon)" affect } \\
\text { my elective course choice.] }\end{array}$ & 100,5593 & 329,029 & 0,243 & 0,908 \\
\hline $\begin{array}{l}\text { [5. The "similarity to courses I have } \\
\text { taken and was successful at until now" } \\
\text { affects my elective course choice.] }\end{array}$ & 100,2684 & 320,814 & 0,509 & 0,902 \\
\hline $\begin{array}{l}\text { [6. The "previous elective course(s)" } \\
\text { affects my elective course choice.] }\end{array}$ & 100,3136 & 320,403 & 0,491 & 0,903 \\
\hline $\begin{array}{l}\text { [7. "Whether the course is applied or } \\
\text { not" affects my elective course choice.] }\end{array}$ & 100,0395 & 319,120 & 0,555 & 0,902 \\
\hline $\begin{array}{l}\text { [8. "Whether the course is up-to-date" } \\
\text { affects my elective course choice.] }\end{array}$ & 100,0198 & 317,362 & 0,619 & 0,900 \\
\hline $\begin{array}{l}\text { [9. "Whether the course encourages to } \\
\text { conduct research" affects my elective } \\
\text { course choice.] }\end{array}$ & 100,4294 & 320,642 & 0,518 & 0,902 \\
\hline $\begin{array}{l}{[10 . \text { "The view of the instructor }} \\
\text { towards absenteeism" affects my }\end{array}$ & 99,7316 & 331,851 & 0,230 & 0,908 \\
\hline
\end{tabular}


[11. "My views about the instructor of the course" affect my elective course 99,4068

[12. "The academic career of the lecturer of the course" affects my elective course choice. (Prof. Dr. 100,7345

Assoc. Prof. Dr. - Dr. Lecturer)".]

[13. "The lecturers I consult" affect my elective course choice.]

[14. The "examination type (written, oral, test, etc.)" affects my elective 99,6073 course choice.]

[15. The "possible contribution of the course to my professional life" affects my elective course choice.]

[16. The "possible contribution of the course to my academic development" affects my elective course choice.]

[17. The "possible contribution of the course to my personal development" 99,8559

[18. The "possible contribution of the course to my knowledge of general culture" affects my elective course 99,9463 choice.]

[19. The "possible contribution of the course to my theoretical knowledge" 100,0000

[20. The "possible contribution of the course to my practical knowledge" 100,0339

affects my elective course choice.]

[21. "My personal interests" affect my elective course choice.]

99,6582

318,390

0,645

0,900

[22. "My personal skills" affect my elective course choice.]

[23. "My expectations" affect my elective course choice.]

[24. "My expectations about academic life" affect my elective course choice.]

[25. The "possibility that the course will raise my grade point average"

affects my elective course choice.]

[26. The "students who have taken that course before" affect my elective course 99,7994 select" affect my elective course 100,0960 choice.]

[28. The "opinions of the people from the later years even if they did not take the course" affect my elective course choice.]

Table 3: The total reliability coefficient

\begin{tabular}{lll}
\hline & Number of Item & Cronbach's $\boldsymbol{\alpha}$ \\
\cline { 2 - 3 } Data form used in the study & 28 & 0,906 \\
\hline
\end{tabular}


Table 4. Data form validity coefficient

\section{Sum of Squares of Factor Loads as a Result of Varimax Rotation}

\begin{tabular}{llll} 
Factor & Total & \% of Variance & $\begin{array}{l}\text { Cumulative Variance } \\
\text { \% }\end{array}$ \\
\hline 1 & & & 26,140 \\
2 & 7,319 & 26,140 & 38,504 \\
3 & 3,462 & 12,363 & 46,994 \\
4 & 2,377 & 8,490 & 53,245 \\
5 & 1,750 & 6,251 & 59,089 \\
\hline
\end{tabular}

Table 5. Tukey's Test of Additivity

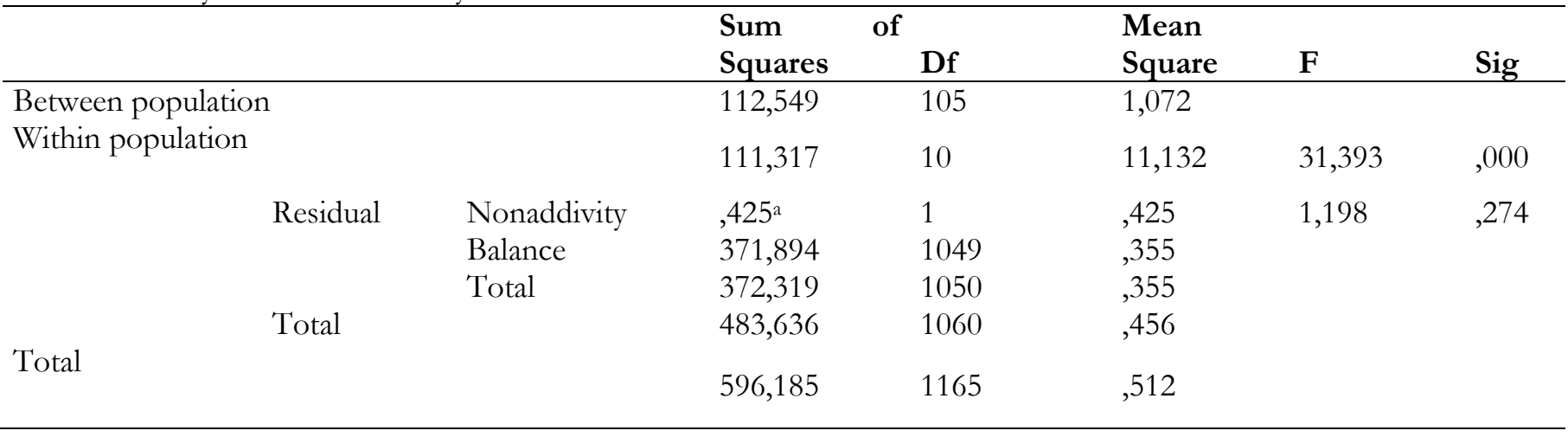

Table 6. Factor loadings

\begin{tabular}{|c|c|c|c|c|c|}
\hline $\begin{array}{l}\text { Elective Course Preference Attitude } \\
\text { Scale }\end{array}$ & $\begin{array}{l}\text { Factor 1: } \\
\text { Additive } \\
\text { Factor }\end{array}$ & $\begin{array}{l}\text { Factor 2: } \\
\text { Personal } \\
\text { Factor }\end{array}$ & $\begin{array}{l}\text { Factor 3: } \\
\text { Structural } \\
\text { Factor }\end{array}$ & $\begin{array}{l}\text { Factor 4: } \\
\text { Instructor } \\
\text { Factor }\end{array}$ & $\begin{array}{l}\text { Factor 5: } \\
\text { Environmental } \\
\text { Factor }\end{array}$ \\
\hline $\begin{array}{l}\text { [1. The "content of the course" affects my } \\
\text { elective course choice.] }\end{array}$ & & & 0,613 & & \\
\hline $\begin{array}{l}\text { [2. The "course selection system" affects } \\
\text { my elective course choice.] }\end{array}$ & & & 0,557 & & \\
\hline $\begin{array}{l}\text { [3. The "way the course is taught } \\
\text { (traditional, student research, presentations, } \\
\text { etc.)" affects my elective course choice.] }\end{array}$ & & & 0,572 & & \\
\hline $\begin{array}{l}\text { [4. The "class hours (whether the class is } \\
\text { in the morning or afternoon)" affect my } \\
\text { elective course choice.] }\end{array}$ & & & 0,698 & & \\
\hline $\begin{array}{l}\text { [5. The "similarity to courses I have taken } \\
\text { and was successful at until now" affects my } \\
\text { elective course choice.] }\end{array}$ & & & 0,400 & & \\
\hline $\begin{array}{l}\text { [6. The "previous elective course(s)" } \\
\text { affects my elective course choice.] }\end{array}$ & & & 0,442 & & \\
\hline $\begin{array}{l}\text { [7. "Whether the course is applied or not" } \\
\text { affects my elective course choice.] }\end{array}$ & & & 0,517 & & \\
\hline $\begin{array}{l}\text { [8. "Whether the course is up-to-date" } \\
\text { affects my elective course choice.] }\end{array}$ & & & 0,685 & & \\
\hline $\begin{array}{l}\text { [9. "Whether the course encourages to } \\
\text { conduct research" affects my elective } \\
\text { course choice.] }\end{array}$ & & & 0,595 & & \\
\hline [10. "The view of the instructor towards & & & 0,448 & & \\
\hline
\end{tabular}


absenteeism" affects my elective course choice.]

[11. "My views about the instructor of the

course" affect my elective course choice.]

[12. "The academic career of the lecturer of the course" affects my elective course choice. (Prof. Dr. - Assoc. Prof. Dr. - Dr. Lecturer)".]

[13. "The lecturers I consult" affect my elective course choice.]

[14. The "examination type (written, oral, test, etc.)" affects my elective course choice.]

[15. The "possible contribution of the course to my professional life" affects my elective course choice.]

[16. The "possible contribution of the course to my academic development" affects my elective course choice.]

[17. The "possible contribution of the course to my personal development" affects my elective course choice.]

[18. The "possible contribution of the course to my knowledge of general culture" affects my elective course choice.]

[19. The "possible contribution of the course to my theoretical knowledge" affects my elective course choice.]

[20. The "possible contribution of the course to my practical knowledge" affects my elective course choice.]

[21. "My personal interests" affect my elective course choice.]

[22. "My personal skills" affect my elective course choice.]

[23. "My expectations" affect my elective course choice.]

[24. "My expectations about academic life" affect my elective course choice.]

[25. The "possibility that the course will raise my grade point average" affects my elective course choice.]

[26. The "students who have taken that

0,793

0,813

0,829

0,720

0,783

0,708

course before" affect my elective course choice.]

[27. The "courses my friends will select" affect my elective course choice.]

[28. The "opinions of the people from the later years even if they did not take the course" affect my elective course choice.] 


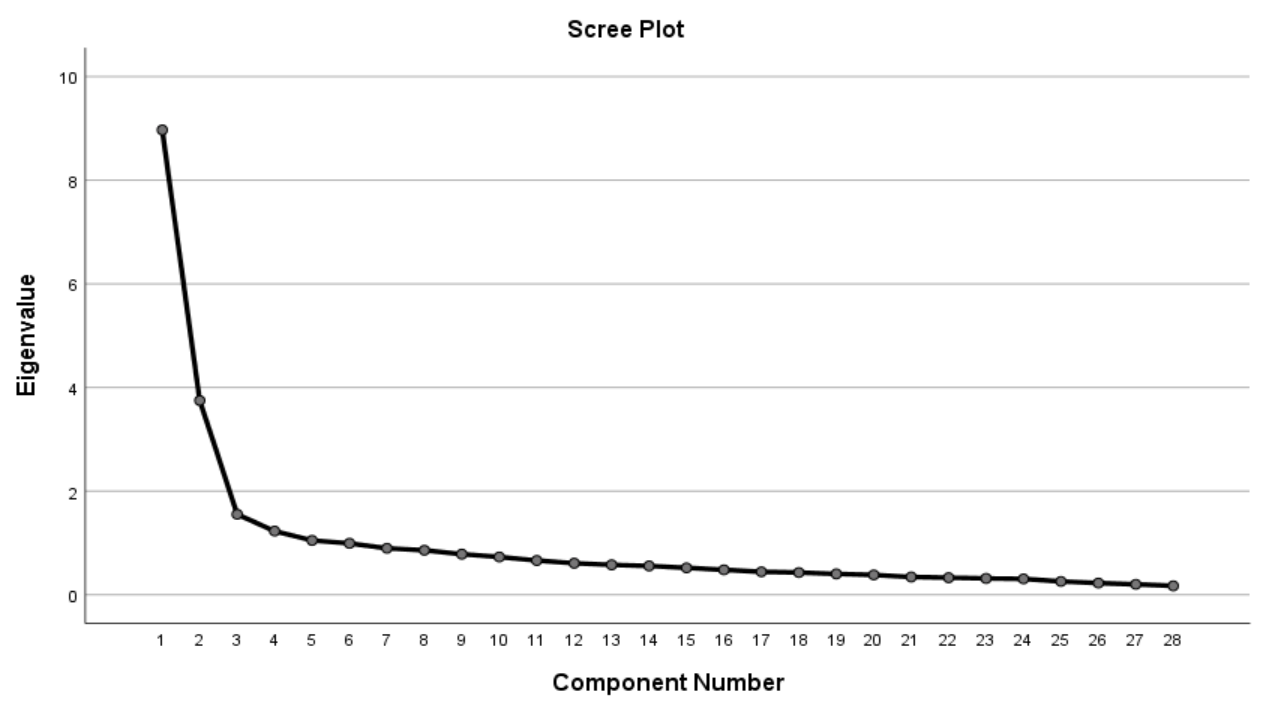

Figure 1. Elective course preferences selection attitude items

\section{DISCUSSION and CONCLUSION}

In terms of reliability analysis, the reliability coefficient as an analysis method is calculated determines the extent to which the items that make up the measurement tool are related to the entirety of the measurement tool and is used frequently in item selection (Bland and Altman 1997, Allen and Yen 2002, Bonett 2002, 2003, 2010, Cronbach and Shavelson 2004). For the construct validity of the scales, total item score analysis is used for validity as well as reliability. The item-total correlation coefficient explains the relationship between the scores obtained from the test items and the total score of the test. That the item-total correlation is positive and high indicates that the items exemplified similar behaviors and the level of internal consistency of the test is high. In a test using Likert-type rating scales, the item-total correlation is calculated by the correlation coefficient (Cronbach and Shavelson 2004). The high correlation obtained for each item indicates that the level of the relation of that item with the theoretical structure is high. In other words, it shows that the item is effective and sufficient to measure the intended behavior (Tezbaşaran 1997). Although not specified, the acceptable selection coefficient is recommended to be greater than 0.20 or even 0.25. It is stated that if deemed necessary, items with a coefficient value between $0.20-0.30$ can be included or should be corrected, and items with a value of less than 0.20 should not be included (Bonett 2002). The studies in the literature state that items with a factor load value of below 0.20 should be removed from the scale (Tezbașaran 1997). Since the items' total correlation value in the study scale was not found to be lower than 0.20 , it was determined that the 28 items in the scale were of high reliability and therefore no item was removed from the prepared data form (Table 2). That none of the 28 items of the scale was removed after the item analysis can be regarded as a very positive development for the study.

Ways to calculate the reliability coefficient differ depending on the type, source, and the number of applications of the variables. The changes in the methods of calculation also change the interpretive meaning of the reliability coefficient. The reliability coefficient is the degree of the nonexistence of random errors and gives information about the amount of error in the measurement results. The reliability obtains values ranging from 0 to +1 , but it is expected to be close to +1 . A coefficient of reliability value of more than 0.70 is a desired result (Cronbach and Meehl 1955). Among the methods recommended in the examination of Likert scales is the Cronbach's alpha $(\alpha)$ technique (Cronbach and Shavelson 2004). In the study, Cronbach's alpha $(\alpha)$ reliability coefficient was found to be 0.906 (Table 3 ). Considering that this coefficient is above 0.80 , it can be said that the study data form is very functional.

The construct validity measured by the factor analysis method is defined as showing the degree of accuracy of the indicators of the theoretical structure to be measured (Balc1 1995, Dempsey and Dempsey 2000). If the KMO value obtained before factor analysis is below 0.50 , it means that the sample size is insufficient, and if the value is between 0.60-0.69 it is deemed to be sufficient (Kaiser 1974, Cerny and Kaiser 1977). However, in order for the sample size to sufficient, the results of Bartlett's sphericity test should be statistically significant as well (Kaiser 1958, 1974). The chi-square value of Bartlett's sphericity test measures the suitability of the data for factor analysis. The higher this value, the more suitable the dataset is for factor analysis (Barlett and Fowler 1937). In this study, the KMO value before the factor analysis was found to be 0.909 and the chi-square value of Bartlett's sphericity test was found to be $\chi^{2}$ $=4921,612$. These results were found to be 
statistically significant $(\mathrm{p}<0.01)$, which shows that the values obtained in the study were suitable for factor analysis $(p<0.05)$. It can also be said that the results of the factor analysis show that the structural validity of the scale was achieved.

In order to obtain a total scale score by the addition of the item scores, Tukey's range test is applied (Tukey 1949). It is seen after the test that the range value of the study was $\mathrm{p}>0.05$ (Table 5 ), and it can be said that the scale is suitable for obtaining a total scale score by the addition of the item scores.

While the eigenvalues of the variables are used to determine the number of factors to be created in the development of a scale, and so is the enthalpyentropy chart proposed by Cattell and Raymond (1966). It is also stated that the enthalpy-entropy graph is more successful than other methods in creating factors. Due to this feature, the enthalpyentropy graph was used to determine the number of factors in the study (Figure 1). However, it can be said that since the study aimed to explain a larger part of the total variability, a 5th main component was included.

In a study conducted by Örs Özdil and Kınay (2015) titled "Scaling 5th Grade Elective Course Preferences with Rank-Order Judgments", a 15-item elective course list offered to the 5th-grade students was given to the 4th-grade students of private and public schools in Ankara affiliated with the Ministry of National Education, and they were asked to score these courses. It is seen that scaling was made according to the scoring performed in the study. Yaşar (2014) conducted a study titled "Developing an Attitude Scale Related to Scientific Research Methods Course" with students of Pamukkale University, Faculty of Education in the academic year 2011-2012. In the study, 20 questions and 4 sub-factors were determined. One of the factors includes the dimensions of "Daily Life and Occupational Relations". Kilınç and Salman (2007) developed a 20-item School Experience Lessons Scale of Attitude (ODDTÖ) in the study titled "Developing an Attitude Scale towards the Lessons of School Experience" conducted with students in the departments of Mathematics, Physics, Chemistry, and Biology. In the study, a scale consisting of 28 questions and 5 factors was developed (Table 6). It is seen in the literature that no scale studies were conducted on the attitude of veterinary medicine students in specific and university students in general towards elective course preferences. The data obtained with the study shows that the developed scale can be used to investigate the elective course preferences of veterinary medicine students, and it can also be used to evaluate elective course preferences of students in other departments.

In conclusion, the research findings suggest that the "Elective Course Preference Attitude Scale" is reliable and valid to be used with veterinary medicine students and can be used to evaluate the reasons for students' elective course preferences.
Ethics Committee Approval: Selcuk University, Faculty of Veterinary Medicine, Ethic Committee, 27.02.2020 dated, 2020/24 numbered of decision.

Conflict of Interest: The authors have no conflicts of interest to declare.

\section{REFERENCES}

Allen MJ, Yen WM. Introduction to Measurement Theory. IL: Waveland Press, Long Grove. 2002.

Balcı A. Sosyal Bilimlerde Araştırma Yöntem, Teknik ve İlkeler. Ankara Üniversitesi Eğitim Bilimleri Fakültesi, Ankara. 1995.

Bartlett MS, Fowler RH. Properties of sufficiency and statistical tests. Proc. R. Soc. Lond. 1937; A160:268-282.

Bland JM, Altman DG. Statistics notes: Cronbach's alpha. BMJ. 1997; 314(7080):572.

Bonett DG. Sample size requirements for testing and estimating coefficient alpha. Journal of Educational and Behavioral Statistics.2002; 27:335-340.

Bonett DG. Sample size requirements for comparing two alpha reliability coefficients. Applied Psychological Measurement. 2003; 27:72-74.

Bonett DG. Varying coefficient meta-analytic methods for alpha reliability. Psychological Methods. 2010; 15:368-385.

Cattell RB, Raymond B. The scree test for the number of factors. Multivariate Behavioral Research. 1966; 1(2):245276.

Cerny CA, Kaiser HF. A study of a measure of sampling adequacy for factor-analytic correlation matrices. Multivariate Behavioral Research. 1977; 12(1):43-47.

Cronbach LJ, Meehl PE. Construct validity in psychological tests. Psychological Bulletin. 1955; 52(4):281-302.

Cronbach LJ, Shavelson RJ. My current thoughts on coefficient alpha and successor procedures. Educational and Psychological Measurement. 2004; 64(3):391-418.

Dempsey PA, Dempsey AD. Using nursing research process, critical evaluation and utilization. 5th Edition, Lippincott, Philadelphia-New York, 2000.

Durmuşçelebi M, Mertoğlu B. Ortaokul öğrencilerinin eğitiminde seçmeli derslerin yeri. Uluslararası Toplum Araştırmaları Dergisi Gençlik Araştırmaları Özel Sayısı. 2018; 8:170-211.

Dündar S. Ders seçiminde analitik hiyerarşi proses uygulaması. Süleyman Demirel Üniversitesi İ̈BF Dergisi. 2008; 13(2):217-226.

EARGED (2008): Seçmeli derslerin seçim kriterlerinin değerlendirilmesi araştırması. Milli Eğitim Bakanlığı. Available https://www.meb.gov.tr/earged/earged/secmeli_dersler _arastirmasi.pdf_Accessien date: 01.05.2020

Ersöz F, Kabak M, Yılmaz Z. Lisansüstü öğrenimde ders seçimine yönelik bir model önerisi. Afyon Kocatepe Üniversitesi, İIBF Dergisi. 2011; 8(2):227-249. 
Kaiser HF. The varimax criterion for analytic rotation in factor analysis. Psychometrika. 1958; 23(3):187-200.

Kaiser HF. An index of factor simplicity. Psychometrika. 1974; 39(1):31-36.

Kılınç A, Salman S. Okul deneyimi derslerine yönelik tutum ölçeği geliştirilmesi. GÜ Gazi Eğitim Fakültesi Dergisi. 2007; 27(1): 23-35.

Kutlu BS, Abalı YA, Eren T. Çok ölçütlü karar verme yöntemleri ile seçmeli ders seçimi. Sosyal Bilimler. 2012; 2(2):5-25.

Örs Özdil S, Kınay E. 5. Sınıf ders tercihlerinin sıralama yargıları kanunuyla ölçeklenmesi. Eğitimde ve Psikolojide Ölçme ve Değerlendirme Dergisi. 2015; 6(2):268-278.

Tezbaşaran A. Likert tipi ölçek geliştirme klavuzu. 2. Baskı. Türk Psikologlar Derneği Yayınları, Ankara, 1997.

Tezcan H, Gümüş Y. Üniversite öğrencilerinin seçmeli ders tercihlerine etki eden faktörlerin araştırılması. GÜ, Gazi Eğitim Fakültesi Dergisi, 2008; 28(1): 1-17.

Tukey JW. One degree of freedom for non-additivity. Biometrics. 1949; 5(3):232-242.

Yaşar M. Bilimsel araştırma yöntemleri dersine yönelik tutum ölçeği geliştirme çalışması: Geçerlik ve güvenirlik. EBADJESR. 2014; 4(2): 109-129. 
APPENDIX 1: Elective Course Preference Attitude Scale (Turkish)

\section{Seçmeli Ders Tutum Ölçeği}

1. Seçmeli ders tercihimde "dersin içeriği" etkili oluyor.

2. Seçmeli ders tercihimde "ders seçme sisteminin" etkisi oluyor.

3. Seçmeli ders tercihimde "dersin işlenme biçimi (geleneksel anlatım, öğrenci araştırması, öğrenci sunumu vb)" etkili oluyor

4. Seçmeli ders tercihimde "ders saatleri (sabah veya öğleden sonra olması)" etkili oluyor.

5. Seçmeli ders tercihimde "şimdiye kadar almış olduğum ve başarılı olduğum derslere yakın olması" etkili oluyor.

6. Seçmeli ders tercihimde "daha önce almış olduğum seçmeli ders/ler" etkili oluyor.

7. Seçmeli ders tercihimde "dersin uygulamalı olup olmaması" etkili oluyor.

8. Seçmeli ders tercihimde "alacağım dersin güncel olup olmaması" etkili oluyor.

9. Seçmeli ders tercihimde "dersin araştırmaya teşvik edici olup olmaması" etkili oluyor.

10. Seçmeli ders tercihimde "devamsızlı sorunu olmaması" etkili oluyor.

11. Seçmeli ders tercihimde "dersi veren öğretim üyesi hakkındaki görüşlerim” etkili oluyor.

12. Seçmeli ders tercihimde "dersi veren öğretim üyesinin akademik kariyeri (Prof.Dr.-Doç.Dr.Dr.Öğr.Üyesi)" etkili oluyor.

13. Seçmeli ders tercihimde "danıştı̆̆ım öğretim üyeleri”" etkili oluyor.

14. Seçmeli ders tercihimde "dersi veren öğretim üyelerinin sinav sistemi (yazılı, sözlü, test vb)" etkili oluyor.

15. Seçmeli ders tercihimde "meslek hayatıma katk1 sağlayabilecek olması" etkili oluyor.

16. Seçmeli ders tercihimde "akademik gelişimime katk1 sağlayabilecek olması" etkili oluyor.

17. Seçmeli ders tercihimde "dersin kişisel gelişimime katk1 sağlayabilecek olması” etkili oluyor.

18. Seçmeli ders tercihimde "dersin genel kültürüme katk1 sağlayabilecek olması” etkili oluyor.
19. Seçmeli ders tercihimde "teorik bilgilerimi artırabilecek olması" etkili oluyor.

20. Seçmeli ders tercihimde "pratik becerilerimi artırabilecek olması" etkili oluyor.

21. Seçmeli ders tercihimde "kişisel ilgilerim" etkili oluyor.

22. Seçmeli ders tercihinde "kişisel yeteneklerim" etkili oluyor.

23. Seçmeli ders tercihimde "kişisel beklentilerim" etkili oluyor.

24. Seçmeli ders tercihimde "akademik hayatla ilgili beklentilerim" etkili oluyor.

25. Seçmeli ders tercihimde "not ortalamamın artabilecek olması" etkili oluyor.

26. Seçmeli ders tercihimde "daha önce o dersi almış olan öğrenciler” etkili oluyor.

27. Seçmeli ders tercihimde "arkadaş çevremin seçeceği dersler” etkili oluyor.

28. Seçmeli ders tercihimde "o dersi almasa da üst sınıf öğrencilerin görüşleri” etkili oluyor. 